\title{
Monitoring the in-situ Bioremediation of Spend engine-oil contaminated soil After Irrigation with Fermented Chicken-droppings
}

\author{
*1 OKPASHI, VE; ${ }^{2}$ USHIE, OA; ${ }^{3}$ ABENG, FE; ${ }^{4}$ INYANG, IH \\ ${ }^{I}$ Department of Biochemistry, ${ }^{3}$ Department of Chemistry, ${ }^{4}$ Department of Microbiology, Cross River University of Technology, Calabar- \\ Nigeria \\ ${ }^{2}$ Department of Chemical Sciences, Federal University, Wukari, Taraba State Nigeria \\ *Corresponding AuthorEmail:vic2reshu@gmail.com
}

\begin{abstract}
Preparation for the bioremediation of petroleum contaminants is explored to provide a low-cost and capable strategy for biodegradation of contaminants and renewal of soil fertility. In this study, fermented chicken droppings were used as novel in-situ bio-stimulants and bio-augmentation materials. The investigation determines the capability of fermented chicken droppings to biodegrade the residual total petroleum hydrocarbon compounds in-used engine oil contaminated soil - in the case of auto mechanic shops. The soil was collected at $10 \mathrm{~cm}$ depth from the ground, air-dried and sieved with $2.5 \mathrm{~mm}$ mesh. A $4 \mathrm{~kg}$ of soil was weighed into 13 perforated buckets to allow aeration and prevent waterlogging. The setup consists of three replicates that were spiked with $150 \mathrm{ml}$ of used engine oil. $500 \mathrm{ml}$ of the fermented chicken droppings were used to irrigate the contaminated soil at ratio 1:8 periodically for every 3 days per irrigation for 21 days. The uncontaminated soil used as the control group was irrigated with normal water. The TPH composition of the contaminated and remediated soil samples was screened using gas Chromatography tandem mass spectroscopy. Results show that the uncontaminated soil (A-group) had C10 - $24.058 \pm 0.02 \mathrm{ppm}, \mathrm{C} 12-37.327 \pm 0.01$ ppm, C14 - $28.515 \pm 0.02 \mathrm{ppm}$ and C16 $-12.097 \pm 0.02 \mathrm{ppm}$, respectively out of about $35 \mathrm{TPH}$ compounds that ought to be detected from $\mathrm{C} 8$ to $\mathrm{C} 40$. The Concentration of TPH in Contaminated soil before irrigation with Chicken droppings - positive control (ppm) B-group gave a significant qualitative and quantitative presence of TPHs in contaminated soil at varying concentrations. $36 \mathrm{TPHs}$ were detected out of forty, starting from C10 - $1.836 \pm 0.01 \mathrm{ppm}$ to $\mathrm{C} 38-50.150 \pm 0.01$ ppm. Whereas, the Concentration of residual TPH in Contaminated soil after irrigation with Chicken droppings gave varying levels of residual TPHs ranging from $\mathrm{C} 8-1.519 \pm 0.02 \mathrm{ppm}$ to $\mathrm{C} 38-41.487 \pm 0.02 \mathrm{ppm}$. This also gave a resultant/differences in the degradation level of TPHs. Differences in TPH Concentration between before the irrigation and after irrigation of contaminated soil were calculated, C8 had - $0.317 \mathrm{ppm}$ while another TPHs concentration varies accordingly. From the results, one can be deduced that despite other environmental factors that influence the degradation of TPHs, fermented chicken droppings showed great capability in the degradation of TPHs in the contaminated soil.
\end{abstract}

DOI: https://dx.doi.org/10.4314/jasem.v24i3.2

Copyright: Copyright $(\mathbb{C} 2020$ Okpasi et al. This is an open access article distributed under the Creative Commons Attribution License (CCL), which permits unrestricted use, distribution, and reproduction in any medium, provided the original work is properly cited.

Dates: 25 January 2020; Revised: 11 February 2020; Accepted: 22 February 2020

Keywords: Bioremediation, auto-mechanic-yard, Soil-fertility, Used-engine-oil, fermented-chicken-droppings

The rise in the global population has increased the exploitation of nature as a response to the high demands for energy. In the past twenty years, pollution in the environment has been on the increase due to human exploration of reserve and conserved energy, unguided agricultural practices and growing industrialization (Abdulsalam et al., 2012; Adu et al., 2015). The stressors with environmental challenges caused by their toxicities including petroleum hydrocarbons, nuclear-wastes, pesticides, and herbicides are wildly spread in the ecosystem. Total petroleum which is usually referred to as crude oil, or "black gold" is a natural fossil fuel composed of hydrocarbons and played a vital role in the growth and advancement of a nation (Ekpo and Udofia, 2008). The essentiality of petroleum hydrocarbon compounds to life has been established (Todd et al., 1999). Since they do not occur in the arrangements that can be advantageous to humans, they can be harmful. This is the prime cause of environmental pollution triggered by petroleum products (Idowu, 2012). Engine-oil is a single petrochemical product that has been recognized over the years as a required emollient for motor engines (Abdulyekeen et al., 2016). Though this machine-oil concentrates the environment with hazardous constitutes that threaten the soil ecosystem (Edewor et al., 2004), that is because constituents of the lubricant might hoard in the soil strata and cause soil infertility or inhibit soil enzymes activities (Mackay and Fraser, 2000). Sustained contact to petroleum leaks may cause the development of liver or kidney disease, gene alteration, damage bone marrow and upsurge the risk of the tumor (Mishra et al., 2001). Oil pollution has risky effects on the growth indices of crops (Godleads et al., 2015). In stretched terms, the toxic effects of oil products can affect plants and 
animal development. A heavy coat of oil inhibits the uptake of plants' nutrient and gags growth. Annihilation of plants may affect the whole food net and drops the natural environments of numerous species (HELCOM, 2002). The examination has exposed the basis of oil contamination which is through oil spills (Sagay et al., 2011). A spill is the release of liquefied petroleum hydrocarbon into the environment due to anthropological action. In today's world, oil spills at auto-mechanic yards have been left unguided without regard to its effect on the ecosystem in many countries, and endlessly buildup on the environment (Abdulsalam et al., 2012). There is a crucial need to ascertain the means of eliminating the contaminant, and this has steered extensive interest and research on remediation performances. Bioremediation employs the biodegradation capacity of TPHs by microorganisms or their attributes, as an effective technique to achieve the salvage sites contaminated with oil and hazardous wastes (Semple et al., 2003). Bioremediation can be well-defined as the usage of naturally occurring microorganisms or artificially engineered organisms to decontaminate synthetic chemicals (Nwankwegu et al., 2016). The procedures comprise of bio-stimulation, bioaugmentation, bioventing, slurping, phytoremediation, composting, farming and piles (Gavrilescu, 2010). The knack of microorganisms to consume oil hinge on the concentration and conformation of the polluted soil in the environment (Lee et al.., 2007). The engrossment of microbes in the deprivation of petroleum hydrocarbons in the environment has been recognized as an effective responsive treatment system (Yakubu, 2007). One encouraging technique is the application of organic fertilizers to complement for the inorganic element, mostly nitrogen and phosphorus restrictions in the soil during biodegradation by microorganisms (Abioye et $a l ., 2012$ ). The usefulness of this management system has been contradictory (Okolo et al., 2005). This might be as a result of heterogeneity of the piles of earth and crude oil as well as conceivable interactions amid the soil adjustments and the soil (Knaebel et al., 1994).

An investigation on the subtypes of saprophytes and crude oil-degrading microbes from cow excrement and poultry mucks, suggested that the addition of cow dung or poultry mucks to polluted soils is constructive since it improves the propagation of microflora that curbed the elongation of crude oil in the polluted soil (Onuorah et al., 2018). In another report, the authors opined that inorganic enricher improves bacterial exploitation of petroleum hydrocarbons. The outcome of organic nutrients on biodegradation of lubricant polluted soil was assessed further with a proposition that the addition of organic nutrients improves the microbial application of lubricant (Agbor et al., 2018). The discharge of crude oil on the soil distresses the thermal properties of the soil. The transportation of leaked oil in the subsoil occurs in the manifold segment - (pores filled with water-oil or water-oil) and in a sole phase flow i.e. pores filled with water where hydrocarbons are liquefied (Adams et al., 2014). In this research, the competency of fermented chicken droppings to biodegrade the enduring total petroleum hydrocarbon compounds in-used machine-oil contaminated soil was estimated in-situ by creating a scenario of the auto mechanic yard.

\section{MATERIALS AND METHODS}

Chemicals and Reagents: The chemicals and reagents used for this research were of analytical grade and purchased at JOECHEM Distribution Company limited at the Ogige market, Nsukka, Nigeria.

Collection of soil sample: The soil samples were a mixture of sandy-loam soil, collected from the farm of the Department of Soil Science, University of Nigeria, Nsukka. The soil sample location had not been exposed to petroleum hydrocarbon pollution. The soil was collected at a distance of $10 \mathrm{~cm}$ deep from the ground level and was for air-dried before sieving with $2.5 \mathrm{~mm}$ mesh. A four kilogram of the soil sample was balanced into 13 perforated buckets to permit ventilation and avert waterlog. The sand-filled buckets were placed in an environment with a regulated temperature.

Collection of Amendment Material - chicken droppings: The chicken droppings were collected from a poultry farm at Ogige-Nsukka, Nigeria. The 27 $\mathrm{kg}$ of dried chicken droppings mixing with 27 liters of water in a ratio of $1 \mathrm{~kg}$ : $1 \mathrm{~L}$. The mixture was painstakingly stirred and placed in an air-tight vessel and kept in a temperature-regulated environment. This enables the dried chicken matter to dissolve and ferment to intensify the microbial mass of the mixture. The chicken droppings mixture was allowed for 7 days, after which it was diluted with water and used for irrigation of the contaminated soil.

Collection of Used engine oil: The engine oil used in mixing/spiking the soil was collected from the automechanic yard, of the Department of Mechanical Engineering, University of Nigeria, Nsukka.

Contamination of the soil sample used engine oil: The soil was grouped in triplicates, $150 \mathrm{ml}$ of the used engine oil was mixed with four kilograms of the soil at ratio $1: 27$, and allowed to equilibrate for one week to ensure assimilation of the oil into the soil before the introduction of fermented chicken droppings. 
Irrigation of contaminated soil sample with fermented chicken droppings: A $500 \mathrm{ml}$ of the fermented chicken droppings mixture was introduced into the contaminated soil sample at a measured interval of three days per irrigation for 21 days. After the irrigation period of 21 days, normal water was used to irrigate the soil at a ratio of 1:8.

Estimation Total Petroleum Hydrocarbon (TPH): The method for estimating TPH was adopted by [24]. The oil composition of the contaminated soil sample before irrigation with chicken droppings and after irrigation was determined using Gas Chromatography tandem mass spectroscopy. Fifteen grams of each of the sample was weighed into $50 \mathrm{ml}$ conical flasks, after which $1 \mathrm{ml}$ of $60 \mu \mathrm{g} / \mathrm{ml}$ of the chloro-octadecane surrogate standard was added. A $30 \mathrm{ml}$ of the extraction solvent - dichloromethane was added to extract the oil in the soil. The concoction was agitated robustly in a water bath for five hours and allowed for one hour to stand. Thereafter, the mixture was filtered over Whatman No.1 filter paper. The residue was washed with $20 \mathrm{ml}$ of the extracting solvent and filtered through a funnel. The extracted oil was transferred to a vial and placed on a Gas Chromatograph for analysis. The amount of degraded oil was calculated by deducting the weight of residual oil from the weight of the initial oil, divided by the weight of initial oil and multiplied by 100 , see equation 1

TPH for soil $\left(\frac{\mathrm{mg}}{\mathrm{kg}}\right)=\frac{I R \times T W E}{W S} \quad 1$

Where; IR $=$ instrument reading, TWE $=$ total weight of extract; WS = weight of sample

Condition of GC-MS (Gas Chromatography-Tandem Mass Spectroscopy) during the analysis: The method was adopted from (Okpashi et al., 2017). The following conditions apply to the use of Gas chromatographic-tandem mass spectroscopy techniques. GC/MS-QP2010 Agilent Plus, Ion source temperature: $200.00^{\circ} \mathrm{C}$, Interface temperature: $250.00^{\circ} \mathrm{C}$, Solvent cut time: $2.50 \mathrm{~min}$, Detector gain mode: MS, Detector gain: $0.00 \mathrm{kV}$, Threshold: 2000, Column oven initial temperature: $70.0^{\circ} \mathrm{C}$, Injection final temperature: $250.00^{\circ} \mathrm{C}$, Injection Mode: Split, Flow control mode: linear velocity, Pressure: 116.9 $\mathrm{kPa}$, total Flow: $40.8 \mathrm{ml} \mathrm{min}^{-1}$, Column flow: $1.80 \mathrm{ml}$ $\mathrm{min}^{-1}$, Linear velocity: $49.2 \mathrm{~cm} \mathrm{sec}^{-1}$, Trap and purge flow: $3.0 \mathrm{ml} \mathrm{min}^{-1}$, Split Ratio: 20.0, High-pressure injection: OFF, Carrier Gas: Helium, and Splitter hold: OFF, respectively. The oven rating was as follows: Oven Temp. Program Rate Temperature $\left({ }^{\circ} \mathrm{C}\right)$ Hold
Time (min) Initial: 0.00 70.0 0.00 Final: 10.0 280 5.00, consequently.

Statistical analysis: Investigations were carried out in triplicates and analyzed with Scientific Package for Science Student (SPSS) version 21. A one-way analysis of variance was used to compare the mean difference among samples. Significance was accepted at $p<0.05$. Data are presented in mean \pm standard deviation using descriptive statistics.

\section{RESULTS AND DISCUSSION}

Table 1 shows the results of total petroleum hydrocarbon concentration of uncontaminated soil sample irrigated with normal water - Positive control (ppm) A, concentration of TPH in contaminated soil sample before irrigation with Chicken droppings positive control (ppm) B, Concentration of residual TPH in contaminated soil after irrigation with Chicken droppings for 21 day and the differences in concentration of TPHs between before irrigation and after irrigation -(ppm) of the contaminated soil samples. The quest for advancement, growth, and dominance of the earth has come with the manufacturing of machine that uses petroleum products. These products are wildly used by private organizations, individuals and public service. In Nigeria, the distribution of petroleum products has led to the pollution of terrestrial environments (Onuorah et al., 2018). The effects of this pollution have been shown in decreased agricultural productivity of soil, health hazards, and increased deterioration of natural resources. Given this pollution, responses are made regarding the degradation of petroleum hydrocarbon occasioned by spilled oil, discharged of used grease by auto-mechanic repairers. The formation of remediation techniques that is effective and inexpensive to remediate residual TPHs and restore soil fertility was the thought in this study. This led to the application of organic wastes (fermented chicken droppings) as amendment materials for in-situ bioremediation and conceivable refurbishment of contaminated soil. The availability of high TPHs in the soil affects the spread of native soil microorganisms which slow the degradation of TPHs the polluted soil. By allowing pollution to persevere, microbial activity in the soil is abridged, with the consequence of affecting the rate of plant growth and harvest.

The improvement of the used engine oil-polluted soils with varying levels of $150 \mathrm{ml}$ of organic wastes, was able to reduce the TPHs content of the soil significantly. Thus increasing the degradation potentials of the chicken droppings, as well as reducing the concentration of TPHs in the polluted soil (Stephen and Ijah, 1999). The experiment revealed 
that the contaminated soil treated with chicken droppings improved the rate of degradation by stimulating the microbial activity which produces biosurfactants that break the interface between water in oil or oil in water due to enzymatic reactions (Ibrahim et al., 2017). Photo-oxidation and temperature at $30^{\circ} \mathrm{C}$ - $40^{\circ}$, influenced the rate of biodegradation of the contaminant by increasing its bioavailability and augmenting microbial actions. For instance, the concentration of uncontaminated soil before contamination, and irrigated with normal water Positive control (ppm) A had four TPHs out of forty, at low concentration $-\mathrm{C} 10: 1.058 \pm 0.02 \mathrm{ppm}, \mathrm{C} 12$ : $11.327 \pm 0.01 \mathrm{ppm}, \mathrm{C} 14: 28.515 \pm 0.02 \mathrm{ppm}$ and $\mathrm{C} 16$ : $12.097 \pm 0.02 \mathrm{ppm}$, respectively. After contamination of the soil with used engine oil, the concentration of same TPHs rose to $-\mathrm{C} 10$ : $1.836 \pm 0.01 \mathrm{ppm}, \mathrm{C} 12$ : 14.049 $\pm 0.01 \mathrm{ppm}, \mathrm{C} 14: 41.017 \pm 0.02 \mathrm{ppm}$, and C16: $83.035 \pm 0.03 \mathrm{ppm}$, respectively. This also explained that the presence of TPHs in the soil increases the volume of contamination and inhibit the activities of soil enzymes. Upon irrigation with chicken droppings, the concentration in the soil reduced to C10: $1.519 \pm 0.02 \mathrm{ppm}$, with a residual difference of 0.317 , C12: $11.623 \pm 0.01 \mathrm{ppm}$ with a decline of 2.462 in 21 days. C14: $33.932 \pm 0.01 \mathrm{ppm}$, with a reduction 7.085, and C16: $68.692 \pm 0.03 \mathrm{ppm}$ with the deregulation of 14.343, (Table 1).

Table 1: total petroleum hydrocarbon concentration of uncontaminated soil sample irrigated with normal water

\begin{tabular}{|c|c|c|c|c|c|}
\hline TPHs & $\begin{array}{l}\text { Ret } \\
\text { Time } \\
(\mathrm{min})\end{array}$ & $\begin{array}{l}\text { The concentration } \\
\text { of uncontaminated } \\
\text { soil irrigated with } \\
\text { normal water - } \\
\text { Positive control } \\
\text { (ppm) A }\end{array}$ & $\begin{array}{l}\text { The concentration of } \\
\text { TPH in } \\
\text { Contaminated soil } \\
\text { before irrigation } \\
\text { With Chicken } \\
\text { droppings - positive } \\
\text { control }(p p m) B \\
\end{array}$ & $\begin{array}{l}\text { The concentration } \\
\text { of residual TPH in } \\
\text { Contaminated soil } \\
\text { after irrigation } \\
\text { with Chicken } \\
\text { droppings }\end{array}$ & $\begin{array}{l}\text { Differences in } \\
\text { TPH } \\
\text { Concentration } \\
\text { between before } \\
\text { irrigation and } \\
\text { after irrigation - } \\
\text { (ppm) }\end{array}$ \\
\hline $\mathrm{C} 8$ & 3.133 & - & - & - & - \\
\hline C9 & 4.567 & - & - & - & - \\
\hline $\mathrm{C} 10$ & 6.682 & $24.058 \pm 0.02$ & $1.836 \pm 0.01$ & $1.519 \pm 0.02$ & 0.317 \\
\hline $\mathrm{C} 11$ & 8.286 & - & $10.066 \pm 0.01$ & $8.327 \pm 0.03$ & 1.739 \\
\hline $\mathrm{C} 12$ & 9.706 & $37.327 \pm 0.01$ & $14.049 \pm 0.01$ & $11.623 \pm 0.01$ & 2.462 \\
\hline $\mathrm{C} 13$ & 11.183 & - & $46.346 \pm 0.02$ & $38.340 \pm 0.02$ & 8.006 \\
\hline C14 & 12.447 & $28.515 \pm 0.02$ & $41.017 \pm 0.02$ & $33.932 \pm 0.01$ & 7.085 \\
\hline $\mathrm{C} 15$ & 13.818 & - & $65.019 \pm 0.01$ & $53.788 \pm 0.02$ & 11.231 \\
\hline C16 & 15.532 & $12.097 \pm 0.02$ & $83.035 \pm 0.03$ & $68.692 \pm 0.03$ & 14.343 \\
\hline Pristine & 18.202 & - & $96.834 \pm 0.02$ & $80.107 \pm 0.04$ & 16.727 \\
\hline $\mathrm{C} 17$ & 11.434 & - & $79.029 \pm 0.03$ & $65.378 \pm 0.02$ & 13.651 \\
\hline Phytane & 21.136 & - & $85.023 \pm 0.01$ & $70.337 \pm 0.03$ & 14.686 \\
\hline $\mathrm{C} 18$ & 22.405 & - & $52.562 \pm 0.01$ & $43.482 \pm 0.01$ & 9.08 \\
\hline $\mathrm{C} 19$ & 23.569 & - & $43.227 \pm 0.02$ & $35.760 \pm 0.02$ & 7.467 \\
\hline $\mathrm{C} 20$ & 25.764 & - & $44.634 \pm 0.02$ & $36.924 \pm 0.01$ & 7.71 \\
\hline $\mathrm{C} 21$ & 27.841 & - & $42.588 \pm 0.03$ & $35.231 \pm 0.03$ & 7.357 \\
\hline $\mathrm{C} 22$ & 29.686 & - & $48.156 \pm 0.02$ & $39.838 \pm 0.03$ & 8.318 \\
\hline $\mathrm{C} 23$ & 31.484 & - & $55.138 \pm 0.01$ & $45.613 \pm 0.01$ & 9.525 \\
\hline $\mathrm{C} 24$ & 33.169 & - & $69.663 \pm 0.03$ & $57.630 \pm 0.02$ & 12.033 \\
\hline $\mathrm{C} 25$ & 34.766 & - & $98.668 \pm 0.01$ & $81.625 \pm 0.03$ & 17.043 \\
\hline $\mathrm{C} 26$ & 36.245 & - & $140.646 \pm 0.02$ & $116.351 \pm 0.01$ & 24.295 \\
\hline $\mathrm{C} 27$ & 37.638 & - & $184.094 \pm 0.03$ & $152.295 \pm 0.02$ & 31.799 \\
\hline $\mathrm{C} 28$ & 39.08 & - & $163.846 \pm 0.02$ & $135.544 \pm 0.04$ & 28.302 \\
\hline $\mathrm{C} 29$ & 40.439 & - & $261.008 \pm 0.01$ & $215.923 \pm 0.02$ & 45.085 \\
\hline $\mathrm{C} 30$ & 41.765 & - & $397.860 \pm 0.01$ & $329.136 \pm 0.01$ & 68.724 \\
\hline $\mathrm{C} 31$ & 42.954 & - & $334.226 \pm 0.02$ & $276.494 \pm 0.01$ & 57.732 \\
\hline C32 & 44.246 & - & $286.150 \pm 0.02$ & $236.722 \pm 0.02$ & 49.428 \\
\hline C33 & 45.493 & - & $400.085 \pm 0.03$ & $330.978 \pm 0.01$ & 69.107 \\
\hline C34 & 46.509 & - & $329.730 \pm 0.01$ & $272.775 \pm 0.03$ & 56.955 \\
\hline C35 & 47.852 & - & $45.820 \pm 0.03$ & $37.905 \pm 0.03$ & 7.915 \\
\hline C36 & 49.398 & - & $30.253 \pm 0.02$ & $25.027 \pm 0.04$ & 5.226 \\
\hline C37 & 51.427 & - & $26.221 \pm 0.01$ & $21.692 \pm 0.01$ & 4.529 \\
\hline C38 & 53.019 & - & $50.150 \pm 0.01$ & $41.487 \pm 0.02$ & 8.663 \\
\hline C39 & 54.823 & - & - & - & - \\
\hline $\mathrm{C} 40$ & 57.043 & - & - & - & - \\
\hline
\end{tabular}

Other TPHs that were not initially in the soil, but were present as a result of the contamination with the used engine oil, they ranged from $\mathrm{C} 17$ to $\mathrm{C} 38$. Their concentration varies significantly after mixing with the used engine oil. Thereafter, the application of fermented chicken dropping for 21 days caused a rapid 
and significant decline in the TPHs level of the contaminated soil.

This was attributed to the enzymatic kinetics and emulsification of the oil by enzyme surfactants. The bio-surfactants emulsified the oil droplet size and reduced the rheological interface between the water, soil particles, and oil. The secretion of bio-surfactants by microorganisms increases the proximity of TPHs and microorganisms for the uptake of the contaminants.

In other words, biodegradation occurs via the production of bio-surfactants by microorganisms. The bio-surfactants emulsify the oil and decrease the hydrophobicity, solubilized the oil, increase the bioavailability of TPHs and amassed the capability of the microorganisms to consume the carbon chains as an energy source. The biodegradation ability of the chicken droppings is shown in a concentration difference of $626.54 \mathrm{ppm} \quad(0.06 \%$ percentage difference) in Table 1. Thus, the work of Hwang et al. (2001) reports the bioremediation of hydrocarboncontaminated soil with composting practice and originates the use of remediating contaminated soil by increasing the efficacy of composting. This is because the reprocessed soils typically have acclimatized microorganisms that affected the rate of degradation.

Conclusion: Microbial degradation of hydrocarbons is one of the major mechanisms which cleanup of hydrocarbon polluted environment can be accomplished. Granting that excessive nutrients can inhibit biodegradation, chicken droppings have been recognized as a probable bioremediation agent. Mostly used for both bio-stimulation and bio-augmentation due to its tendency to attract high microbial load. The results in this study showed that chicken droppings supported high spend oil remediation in the polluted soil.

\section{REFERENCES}

Abdulsalam. S: Adefia. SS: Bugaje. IM: Ibrahim. S (2012). Bioremediation of soil contaminated with used motor oil in a closed system. $J$. Bioremediation \& Biodegradation, 3(12): 39.

Abdulyekeen. KA: Muhammad. IM: Giwa. SO: Abdulsalam. S (2016). Bioremediation of used motor oil contaminated soil using elephant and horse dung as stimulants. J. Environ Sci. Toxicol. Food Techno. 10(12): 73-78.

Abioye. OP: Agamuthu. P: Abdul. AA (2012). Biodegradation of Used Motor Oil in Soil Using Organic Waste Amendments. Biotechnology Res. International, 2012; 215: 25-29.
Adams. GO: Tawari-Fufeyin. P: Igelenyah. E (2014). Bioremediation of spent oil-contaminated soils using poultry litter. Research Journal in Engineering and Applied Sciences, 2014; 3 (2):124-130.

Adu. AA: Aderinola. OJ: Kusemiju. V (1015). Comparative effects of spent engine oil and unused engine oil on the growth and yield of Vignaunguiculata (Cowpea). International Journal of Science and Technology, 4(3): 105118.

Agbor. RB: Antai. SP: Nkanang. AJ (2018). Microbial degradation of total petroleum hydrocarbon in crude oil polluted soil ameliorated with agrowastes. Global Journal of Earth and Environmental Science, 3: 1-7.

Edewor. TI: Adelowo. OO: Afolabi. TJ: (2004). Preliminary studies into the biological activities of a broad spectrum disinfectant formulated from used engine oil. Pollution Research, 234: 581586.

Ekpo. MA: Udofia. US (2008). The rate of biodegradation of crude oil by microorganisms isolated from oil sludge environment. African Journal of Biotechnology, 7: 4495-4499.

Gavrilescu. M (2010). Environmental Biotechnology: Achievements, opportunities, and challenges. Dynamic Biochemistry, Process Biotechnology, and Molecular Biology, 4(1): 1-36.

Godleads. OA: Prekeyi. TF: Samson. EO (2015). Ehinomen I. Bioremediation, Biostimulation, and Bioaugmentation: A Review. International Journal of Environmental Bioremediation and Biodegradation, 2015; 3(1): 28-39.

HELCOM. (2002). The Baltic marine environment.Baltic Sea Environment Proceedings, 87, Helsinki Commission.Baltic Marine Environment Protection Commission, 2003.

Hwang. E: Namkoog. W: Park. J (2001). Recycling of remediated soil for effective composting of diesel-contaminated soil. Compost Science and Utilization, 4 (3):143 -149.

Ibrahim. KA: Abdullahi. AI: Muhammad. BY (2017). Remediation of soil contaminated with toxic organic compounds using microorganisms. 
Bayero Journal of Pure and Applied Sciences, 10(1): 148-152.

Idowu. OF (2012). Niger Delta Crisis: Implication for society, and organizational effectiveness. British Journal of Arts and Social Sciences, 7 (11):100.

Knaebel. DB: Federle. TW: McAvoy. DC: Vestal. JR (1994). Effects of mineral and organic soil constituents on microbial mineralization of organic compounds in natural soil. Applied Environmental Microbiology, 60: 4500-4508.

Lee. SH: Lee. S: Kim. DY: Kim. JG (2007). Degradation characteristics of waste lubricants under different nutrient conditions. Journal of Hazardous materials, 143(1): 65-72.

Mackay. D: Fraser. A. (2000).Bioaccumulation of persistent organic chemicals: Mechanisms and models. Environmental Pollution, 111: 375-391.

Mishra. S: Jyot. J: Kuhad. RC: Lal. B (2001). Evaluation of inoculum addition to stimulating in situ bioremediation of oily-sludge-contaminated soil. Applied Environmental Microbiology, 67: 1675-1681.

Nwankwegu. AS: Onwosi. CO: Orji. MU: Anaukwu. CG: Okafor. UC: Azi. F: Marins. PE (2016). Reclamation of DPK hydrocarbon polluted agricultural soil using a selected bulking agent. Journal of Environmental Management, 172: 136-142.

Okolo. JC: Amadi. EN: Odu. CT (2005). Effects of soil treatments containing poultry manure on crude oil degradation in sandy loam soil. App Ecological and Environ. Res, 3: 47-53.
Okpashi. VE: Ogugua. VN: Joshua. PE: Chibuike. SU: Obinna. AO: David. MA: Robert. IU: Ikechukwu. NO (2017). Comparability Assessment of Polycyclic Aromatic Hydrocarbons Tissue Load in Some Fish: Implication on Reciprocal Synergism and Risk Assessment. American Journal of Environmental Sciences, 13(2): 182190

Onuorah. S: Soludo. C: Odibo. F (2018). Impact of pig manure on the chemical characteristics and microbial population of crude oil-polluted soil in Awka, Nigeria. American Journal of Life Science Researches, 6(1):47-59.

Sagay. J: Edo. ZO: Avweromre. L (2011). Environmental Degradation and the Dilemma of Sustainable Development: Implication for Environmental Security in the Niger. Journal of Environmental Sciences and Resource Management, 3:14-29.

Semple. KT: Morriss. AWJ: Paton. Gl (2003). Bioavailability of hydrophobic organic contaminants in soils: fundamental concepts and techniques for analysis. European Journal of Soil Science, 54: 809-818.

Stephen. E: Ijah. UJ (1999). Comparison of Glycine $\max$ and Sidaacutain the phytoremediation of waste lubricating oil polluted the soil. National Science, 9 (8): 190-193.

Todd. GD: Chessin. RL: Colman. J (1999). Toxicological profile for Total Petroleum Hydrocarbons (TPH). The US Department Of Health and Human Services. Public Health Service. USA: 453.

Yakubu. MB (2007). Biodegradation of Lagoma crude oil using pig dung. African Journal of Biotechnology, 6: 2821-282. 